\section{Effects of Soil-applied Imazapic on Pecan Production}

\author{
M. Lenny Wells ${ }^{1,3}$ and Eric P. Prostko ${ }^{2}$
}

AdDitional INDEX words. Carya illinoinensis, kernel development, shuck-split

Summary. A persistent problem was identified in pecan (Carya illinoinensis) orchards throughout southern Georgia in which pecan trees growing in rows immediately adjacent to peanut (Avachis hypogaea) fields developed hollow pecans. In-shell nut size and appearance was normal; however, the kernels failed to develop. In 2008 and 2009, research was conducted to evaluate the influence of imazapic on pecan nut development in two pecan orchards located at the University of Georgia Ponder Research Farm located near Tifton, GA. Three herbicide treatments were evaluated, including imazapic at $0.17 \mathrm{~kg} \cdot \mathrm{ha}^{-1}$, imazapic at $0.30 \mathrm{~kg} \cdot \mathrm{ha}^{-1}$, and a nontreated control. Imazapic inhibited pecan kernel production and shuck split during both years of study. In 2009, leaf potassium was reduced by the low rate of imazapic.

$\mathrm{P}$ ecan orchards in the southeastern United States are often found growing adjacent to fields of annual row-crops. There can be multiple advantages and/or disadvantages to this situation for both crops. The roots of mature pecan trees can extend to a length twice the width of the tree canopy (Hammar et al., 1953; Woodroof and Woodroof, 1934). Pecan tree roots extending into an adjacent row crop field can compete with the row crop for available soil water and nutrients (Allen et al., 2004a, 2004b; Diomides et al., 2006; Wanvestraut et al., 2004). To date, most studies on the effects of interactions between pecans and row crops have focused solely on the row crop.

Pecans and peanuts are highly valuable to agricultural profitability in the southeastern United States. When combined, these crops account for over $\$ 510$ million in farm gate value for Georgia alone (McKissick and Boatright, 2007). Pecans and peanuts may also be grown in close proximity in Alabama, Florida, Oklahoma, and Texas. Due to the importance of these crops to agriculture in these areas and their often close proximity to each other, it is important that the production practices of both crops be compatible.

A persistent problem was identified in pecan orchards throughout southern Georgia in which pecan trees

${ }^{1}$ University of Georgia, Department of Horticulture 4604 Research Way, Tifton, GA 31793

${ }^{2}$ University of Georgia, Department of Crop and Soil Sciences, 104 Research Way, Tifton, GA 31793

${ }^{3}$ Corresponding author. E-mail address: lwells@uga. edu. growing in rows immediately adjacent to peanut fields developed hollow pecans. In-shell nut size and appearance was normal; however, the kernels failed to develop (Fig. 1). Frequent observations in multiple orchards suggested that this problem only occurred where peanuts were planted adjacent to pecan orchards. It was never observed in orchards adjacent to other row crops. One additional case was observed in a row of pecan trees adjacent to a highway right-of-way.

Imazapic is a popular postemergence herbicide used in peanut fields early in the growing season to control various broadleaf weeds, grasses, and sedges (Grichar and Nester, 1997; Richburg et al., 1996; Webster et al., 1997). Imazapic is rapidly absorbed by plant roots and shoots, transferred to other parts of the plant, and accumulates in actively growing tissues (Shaner and Singh, 1998). Due to its soil residual activity, imazapic has long rotation restrictions before subsequent crops can be planted (Grymes et al., 1995; Matocha et al., 2003; York et al., 2000). Imazapic is also frequently used in weed management programs along highway right-of-ways.

Due to its wide-scale use in peanut fields and right-of-ways, it was suspected that imazapic was a potential cause of the "hollow pecans" described above. The objective of this study was to investigate the effect of imazapic on pecan production.

\section{Materials and methods}

Studies were conducted in two pecan orchards located at the University of Georgia Ponder Research Farm located near Tifton, GA. Orchard soils were Fuquay loamy sand (loamy, siliceous, thermic Arenic Plinthic Paleudult) in 2008 and Tifton loamy sand (fine-loamy, siliceous, thermic Plinthic Paleudult) in 2009. Trees were managed according to University of Georgia Cooperative Extension recommendations (Hudson et al., 2009). Three treatments were evaluated, including imazapic (Cadre ${ }^{\circledR}$ 2AS; BASF, Research Triangle Park, NC) at 0.17 $\mathrm{kg} \cdot \mathrm{ha}^{-1}$, imazapic at $0.30 \mathrm{~kg} \cdot \mathrm{ha}^{-1}$, and a nontreated control. All treatments were applied with a carbon dioxidepressurized backpack sprayer calibrated to deliver $140 \mathrm{~L} \cdot \mathrm{ha}^{-1}$ using flat fan spray tips (11002DG; TeeJet Technologies, Springfield, IL). Treatments were applied in June, during the early to mid nut-sizing period, of both years to the soil beneath the canopy of the pecan tree beginning $\approx 6 \mathrm{ft}$ from the trunk and extending out to $\approx 40 \mathrm{ft}$ from the trunk to ensure application within the tree's root zone. Treatments were arranged in a randomized complete block design with single tree plots, and all treatments were replicated three times.

In 2008, treatments were applied beneath $\approx 60$ to 70 -year-old 'Schley' pecan trees spaced $80 \times 80 \mathrm{ft}$. Due to the availability of trees in 2009 , treatments were applied beneath three USDA selections [70-6-15 ('Kiowa' $\times$ 'Desirable'), 74-4-3 ('Chickasaw' $\times$ 'Cheyenne'), and 76-7-41 ('Cherokee' $\times$ 'Choctaw')] spaced at $40 \times 40$ $\mathrm{ft}$ in the Ponder Variety Grove. All trees were $\approx 30$ years old. Because the hollow kernel problem had been observed

\begin{tabular}{llll}
\hline $\begin{array}{l}\text { Units } \\
\text { To convert U.S. to SI, } \\
\text { multiply by }\end{array}$ & U.S. unit & SI unit & $\begin{array}{l}\text { To convert SI to U.S., } \\
\text { multiply by }\end{array}$ \\
\hline 0.3048 & $\mathrm{ft}$ & $\mathrm{m}$ & 3.2808 \\
9.3540 & gal/acre & $\mathrm{L} \cdot \mathrm{ha}^{-1}$ & 0.1069 \\
25.4 & inch $(\mathrm{es})$ & $\mathrm{mm}$ & 0.0394 \\
1.1209 & $\mathrm{lb} / \mathrm{acre}$ & $\mathrm{kg} \cdot \mathrm{ha}^{-1}$ & 0.8922 \\
1 & $\mathrm{meq} / 100 \mathrm{~g}$ & $\mathrm{cmol} \cdot \mathrm{kg}^{-1}$ & 1 \\
1 & $\mathrm{ppm}$ & $\mathrm{mg} \cdot \mathrm{kg}^{-1}$ & 1 \\
$\left({ }^{\circ} \mathrm{F}-32\right) \div 1.8$ & ${ }^{\circ} \mathrm{F}$ & ${ }^{\circ} \mathrm{C}$ & $\left(1.8 \times{ }^{\circ} \mathrm{C}\right)+32$
\end{tabular}


on multiple cultivars, it was expected that the cultivar effect would be minimal to nonexistent; therefore, 2009 data were pooled over pecan selections, with each selection serving as one replication. All trees were scheduled for removal in 2010.

Foliage was sampled in late July 2009 by collecting 30 leaflet pairs per tree. All leaflet samples were taken from the middle leaf of sun exposed terminals. Leaflet samples were washed in a dilute phosphate-free detergent solution $(0.1 \%$ detergent), followed by rinsing with deionized water. Leaves were then dried to a constant weight at $80{ }^{\circ} \mathrm{C}$ and were ground in a Wiley mill (Wiley, Philadelphia) to pass a $1-m m$ screen. Leaves for nitrogen $(\mathrm{N})$ analysis were also ground with mortar and pestle. Samples were analyzed for $\mathrm{N}$ by combustion using a protein/N determinator (FP528; Leco, St. Joseph, MI), whereas remaining nutrients [calcium (Ca), magnesium (Mg), potassium $(\mathrm{K})$, phosphorous $(\mathrm{P})$, sulfur $(\mathrm{S})$, boron $(\mathrm{B})$, zinc $(\mathrm{Zn})$, iron $(\mathrm{Fe})$, manganese $(\mathrm{Mn})$, and copper $(\mathrm{Cu})]$ were measured by an inductive coupled plasma spectrophotometer (ICP) coupled to a Digiblock 3000 (SCP Science, Baie D’Urfé, QC, Canada).

At shuck split, 50 nuts were collected by hand from each tree. Nuts were sliced transversely. The number of hollow and normally filled nuts per sample was estimated visually and counted to determine the percentage of hollow nuts. Shuck split was rated on 14 Oct. 2009 by assessing shuck split on 100 fruit-bearing terminals per tree. The number of shucks splitting was divided by the total number of nuts counted to obtain a percentage rating of shuck split.

Analysis of variance was used to compare all data. Means were separated using Duncan's multiple range test $(P \leq 0.05)$.

\section{Results and discussion}

In 2009, leaf $\mathrm{K}$ was reduced by the $0.17-\mathrm{kg} \cdot \mathrm{ha}^{-1}$ rate of imazapic (Table 1). It is unclear why a similar result was not observed for the 0.30 $\mathrm{kg} \cdot \mathrm{ha}^{-1}$ rate of imazapic. It is possible that leaf elemental concentration may

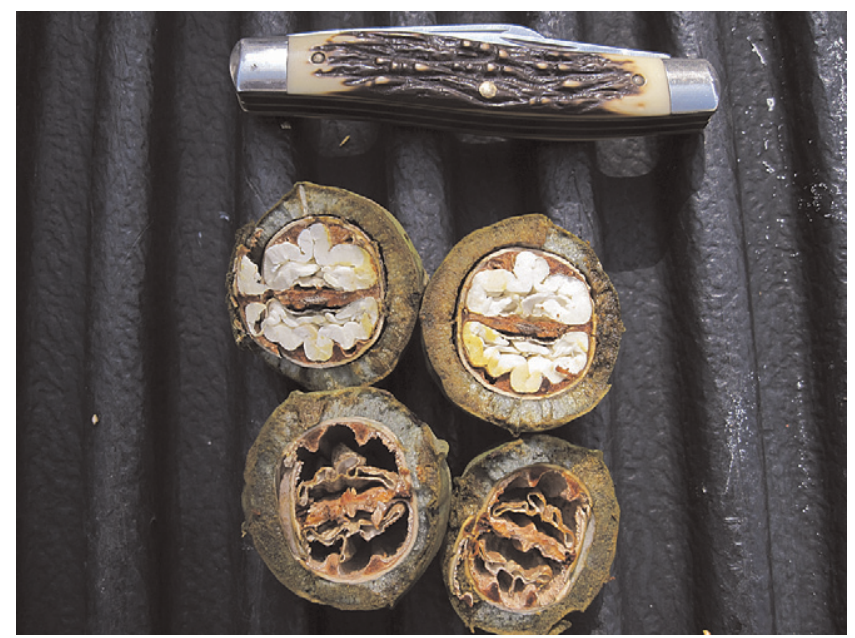

Fig. 1. Hollow pecan kernels following soil application of imazapic within the root zone of pecan trees.

have been affected by genetic differences between pecan selections used in the study. No other elements were affected by treatment.

Pecan kernel filling was significantly affected by soil application of imazapic in both years of study. In 2008 , the $0.30-\mathrm{kg} \cdot \mathrm{ha}^{-1}$ rate of imazapic led to a significant increase in the percentage of hollow pecan kernels ( $\mathrm{Ta}$ ble 2). Kernels were unaffected by the $0.17-\mathrm{kg} \cdot \mathrm{ha}^{-1}$ rate of imazapic. In 2009 , imazapic inhibited kernel development at both rates, with $97 \%$ and $61 \%$ of the kernels failing to develop in the high and low rates, respectively (Table 2 ). The results were consistent across all pecan selections. Although subsequent data were not taken the second year following the 2008 imazapic application, visual observation suggests that the effect of imazapic did not persist beyond the year of application. Trees from the 2009 study were scheduled to be removed in the winter of 2009-10, thus, subsequent data could not be obtained.

One explanation as to the variable response of percentage of hollow kernels between the low and high rates of imazapic in the two orchards is soil type. The Fuquay soil on which the 2008 study was located is a deep sand with only $4 \%$ clay and a cation exchange capacity (CEC) of 5.27 meq/100 g. The 2009 orchard, situated on Tifton loamy sand, has $8 \%$ clay and a CEC of $10.48 \mathrm{meq} / 100 \mathrm{~g}$. Imidazolinone herbicide adsorption and hysteresis can more readily occur with increasing clay content and CEC (Barnes et al., 1989; Goetz et al., 1986, 1990; Magels, 1991; Stougaard et al., 1990). The difference in the attributes of the two soils in this study may have prolonged exposure of the pecan feeder roots to imazapic in soils with high clay content, making the lower rate more damaging to the

Table 1. Leaf elemental concentration of pecan following imazapic application in 2009.

\begin{tabular}{|c|c|c|c|c|c|c|c|c|c|c|c|}
\hline \multirow[b]{2}{*}{ Treatment } & \multicolumn{11}{|c|}{ Leaf element concn ${ }^{\mathrm{z}}$} \\
\hline & $\mathbf{N}(\%)$ & $\mathbf{P}(\%)$ & $\mathrm{K}(\%)$ & $\operatorname{Mg}(\%)$ & $\mathrm{Ca}(\%)$ & S (\%) & $\begin{array}{c}\text { B } \\
(\mathrm{ppm})^{\mathrm{y}}\end{array}$ & $\begin{array}{c}\mathrm{Zn} \\
(\mathrm{ppm})\end{array}$ & $\begin{array}{c}\text { Mn } \\
(\mathrm{ppm})\end{array}$ & $\begin{array}{c}\mathrm{Fe} \\
(\mathrm{ppm})\end{array}$ & $\begin{array}{c}\mathrm{Cu} \\
(\mathrm{ppm})\end{array}$ \\
\hline Imazapic $\left(0.17 \mathrm{~kg} \cdot \mathrm{ha}^{-1}\right)^{\mathrm{y}}$ & $2.47^{\mathrm{x}}$ & 0.12 & $1.17 \mathrm{~b}$ & 0.43 & 1.9 & 0.19 & 29 & 68 & 342 & 44 & 6.3 \\
\hline Imazapic $\left(0.30 \mathrm{~kg} \cdot \mathrm{ha}^{-1}\right)$ & 2.67 & 0.13 & $1.35 \mathrm{a}$ & 0.50 & 1.8 & 0.22 & 38 & 84 & 711 & 49 & 7.0 \\
\hline Control & 2.60 & 0.13 & $1.47 \mathrm{a}$ & 0.49 & 2.0 & 0.21 & 46 & 135 & 579 & 51 & 8.0 \\
\hline
\end{tabular}

${ }^{2}$ The measured nutrients were nitrogen $(\mathrm{N})$, phosphorous $(\mathrm{P})$, potassium $(\mathrm{K})$, magnesium $(\mathrm{Mg})$, calcium $(\mathrm{Ca})$, sulfur $(\mathrm{S})$, boron $(\mathrm{B})$, zinc $(\mathrm{Zn})$, manganese $(\mathrm{Mn})$, iron $(\mathrm{Fe})$, and copper $(\mathrm{Cu})$

${ }^{y} \mathrm{lgg} \cdot \mathrm{ha}^{-1}=0.8922 \mathrm{lb} / \mathrm{acre}, \mathrm{l} \mathrm{ppm}=1 \mathrm{mg} \cdot \mathrm{kg}^{-1}$.

${ }^{\mathrm{x}}$ Columns without letters following means are not significantly different according to Duncan's multiple range test $(P<0.05)$. 
Table 2. Influence of soil-applied imazapic on pecan kernel development in 2008 and 2009.

\begin{tabular}{llc}
\hline Yr & \multicolumn{1}{c}{ Treatment } & Hollow pecan kernels (\%) \\
\hline 2008 & Imazapic $\left(0.17 \mathrm{~kg} \cdot \mathrm{ha}^{-1}\right)^{\mathrm{z}}$ & $3.3 \mathrm{~b}^{\mathrm{y}}$ \\
& Imazapic $\left(0.30 \mathrm{~kg} \cdot \mathrm{ha}^{-1}\right)$ & $74.6 \mathrm{a}$ \\
& Control & $7.3 \mathrm{~b}$ \\
2009 & Imazapic $\left(0.17 \mathrm{~kg} \cdot \mathrm{ha}^{-1}\right)$ & $61.3 \mathrm{~b}$ \\
& Imazapic $\left(0.30 \mathrm{~kg} \cdot \mathrm{ha}^{-1}\right)$ & $97.3 \mathrm{a}$ \\
& Control & $6.0 \mathrm{c}$ \\
\hline
\end{tabular}

${ }^{\mathrm{z}} 1 \mathrm{~kg} \cdot \mathrm{ha}^{-1}=0.8922 \mathrm{lb} /$ acre.

${ }^{y}$ Means in the same column with the same letter are not significantly different according to Duncan's multiple range test $(P<0.05)$.

pecans. Barnes et al. (1989) noted greater cotton (Gossypium hirsutum) injury due to imazaquin on a Skarkey clay soil than on Amagon sandy loam. Grey et al. (2005) also theorized that imazapic remained at higher concentration levels throughout the season because of hysteresis effects that were more evident on soils high in clay content than on sandy soils. This led to greater cotton injury on those soils with higher clay content. Conversely, there is a greater potential for such herbicides to leach quickly below the rhizosphere in a deep sand soil (Stougaard et al., 1990). However, during June 2009, 2.37 inches of rain were recorded at our study site compared with 0.69 inches of rain in 2008. Therefore, leaching does not appear to explain the variation in response to the low herbicide rate. Although imazapic did not appear to affect pecan kernel development in the second year following application on the sandy soil sites used in our study, due to its potential persistence in clay-based soils, there is a possibility that the effects of imazapic could persist on trees growing on clay soils for more than 1 year.

Trees used in the 2009 study were smaller than those in 2008. Thus, there was potentially less dilution of the material in the smaller trees that could have led to greater injury. Genotypic variation between cultivars may also explain the variable response to the low herbicide rate between 2008 and 2009. It is possible that some cultivars may display varying levels of sensitivity to imazapic herbicide, although this has not been directly observed in limited field observations.

Imazapic inhibits activity of acetolactate synthase, an essential enzyme for the production of certain amino acids, leucine, valine, and isoleucine, which are used in protein synthesis (LaRossa and Schloss, 1984; Ware,
2000). Proteins comprise $7.75 \%$ of the pecan kernel (Santerre, 1994). Meredith (1974) suggested that leucine, valine, and isoleucine are major components of pecan kernels. Although the mode of action by which imazapic prevents pecan kernel development remains unknown, it seems likely that its effect on leucine, valine, and isoleucine plays a key role. Chlorosulfuron, an herbicide with a similar mode of action to imazapic, reduced fruit production of cherry (Prunus avium) trees at rates equivalent to $\mathrm{l} /$ 1000 of typical agricultural application rates, while no visible shoot or leaf damage was observed (Fletcher et al., 1993). Although kernel development was affected in our study, there were no externally visible signs of damage on pecan foliage, shucks, or shells.

Shuck split was affected by imazapic application in 2009. About $48 \%$ of pecan shucks failed to dehisce by 14 Oct. 2009 on trees in the 0.30$\mathrm{kg} \cdot \mathrm{ha}^{-1}$ rate plots compared with $20 \%$ in the $0.17-\mathrm{kg} \cdot \mathrm{ha}^{-1}$ rate plots, and $1.3 \%$ in the untreated control plots. Although shuck split was not evaluated in 2008, visual observation of shuck split progression suggested that imazapic delayed or prevented shuck split in 2008 as well. This is consistent with observations from trees in commercial orchards in which shucks on trees in rows adjacent to peanut fields failed to dehisce.

The lack of shuck split in imazapictreated plots likely results from the failure of the kernel to develop. Ethylene is produced by mature pecan kernels (Lipe and Morgan, 1970, 1973 ) and moves through the fruit/ shuck tissues, stimulating enzyme activity at the sutures, and breaks down cells along the suture, causing the shucks to split (Sparks and Yates, 1995). It is possible that because no mature kernel was present to produce ethylene in imazapic-treated plots, shuck dehiscence failed to occur.

Imazapic does not volatize from the soil surface (Cox, 2003; Jenkins et al., 2000), and drift during application was not a factor in our experiment, which would suggest that imazapic was probably absorbed by the pecan roots. Although root absorption was not directly studied, this research suggests that imazapic application near pecan roots can result in inhibition of kernel development and shuck dehiscence. As a result, precautions should be observed with the use of imazapic near pecan trees. This becomes particularly important where peanuts are grown in fields adjacent to pecan orchards and along highway right of ways.

\section{Literature cited}

Allen, S., S. Jose, P.K.R. Nair, B.J. Brecke, P. Nkedi-Kizza, and C.L. Ramsey. 2004a. Safety net role of tree roots: Evidence from a pecan-cotton alley cropping system in the southern United States. For. Ecol. Mgt. 192:395-407.

Allen, S., S. Jose, P.K.R. Nair, B.J. Brecke, P. Nkedi-Kizza, and C.L. Ramsey. 2004b. Competition for ${ }^{15} \mathrm{~N}$-labeled fertilizer in a pecan-cotton alley cropping system in the southern United States. Plant Soil 263:151-164.

Barnes, C.J., A.J. Goetz, and T.L. Lavy. 1989. Effects of imazaquin residues on cotton. Weed Sci. 37:820-824.

Cox, C. 2003. Herbicide factsheet. Imazapic. J. Pesticide Reform 23:10-14.

Diomides, S.Z., J. Shibu, P.K.R. Nair, and C.L. Ramsey. 2006. Interspecific competition in a pecan-cotton alleycropping system in the southern United States: Production and physiology. Can. J. Bot. 84:1686-1694.

Fletcher, J.S., T.G. Pfleeger, and H.C. Ratsch. 1993. Potential environmental risks associated with the new sulfonylurea herbicides. Environ. Sci. Technol. 27:2250-2252.

Goetz, A.J., G. Wehtje, R.H. Walker, and B. Hajek. 1986. Soil solution and mobility characterization of imazaquin. Weed Sci. 34:788-793.

Goetz, A.J., T.L. Lavy, and E.E. Gbur. Jr. 1990. Degradation and field persistence of imazathapyr. Weed Sci. 38:421-428.

Grey, T.L., E.P. Prostko, C.W. Bednarz, and J.W. Davis. 2005. Cotton response to simulated imazapic residues. Weed Technol. 19:1045-1049. 
Grichar, W.J. and P.R. Nester. 1997. Nutsedge (Cyperus spp.) control in peanut (Arachis hypogaea) with AC 263,222 and imazethapyr. Weed Technol. 11: 714-719.

Grymes, C.F., J.M. Chandler, and P.R. Nester. 1995. Response of soybean (Glycine max) and rice (Oryza sativa) rotation to AC 263,222. Weed Technol. 9:504511.

Hammar, H.E., C.L. Smith, and A.O. Alben. 1953. Boron uptake as a criterion of the root spread of pecan trees. Proc. Amer. Soc. Hort. Sci. 62:131-134.

Hudson, W., J. Brock, S. Culpepper, and L. Wells. 2009. Georgia pecan pest management guide. Univ. Georgia Coop. Ext. Bul. 841.

Jenkins, S.R., G.R. Wehtje, J.M. Morgan, A.F. Bollinger, and D.G. Young. 2000. Temperature effects of atrazine and imazapyr on soils. Water Air Soil Pollut. 118:169-178.

LaRossa, R.A. and J.V. Schloss. 1984. The sulfonylurea herbicide sulfometuron is an extremely potent and selective inhibitor of acetolactate synthase in Salmonella tryphimurium. J. Biol. Chem. 259: 8753-8757.

Lipe, J.A. and P.W. Morgan. 1970. Ethylene: Involvement in shuck dehiscence in pecan fruits. HortScience 5:266-267.
Lipe, J.A. and P.W. Morgan. 1973. Location of ethylene synthesis in dehiscing pecan fruits. HortScience 8:320.

Magels, G. 1991. Behavior of the imidazolinone herbicides in soil: A review of the literature, p. 191-209. In: D.L. Shaner and S.L. O'Connor (eds.). The imidazolinone herbicides. CRC Press, Boca Raton, FL.

Matocha, M.A., W.J. Grichar, S.A. Senseman, C.A. Gerngross, B.J. Brecke, and W.K. Vencill. 2003. The persistence of imazapic in peanut (Arachis hypogaea) crop rotations. Weed Technol. 17:325-329.

McKissick, J.C. and S.R. Boatright. 2007. 2007 Georgia farm gate value report. 27 Oct. 2009. <http://commodities.caes.uga. edu/turfgrass/georgiaturf/Publicat/ PCRP2009/FarmGate.pdf>.

Meredith, F.I. 1974. Amino acid composition and quality in selected varieties of pecans. Proc. Florida State Hort. Soc. 87:362-365.

Richburg, J.S., III, J.W. Wilcut, D.L. Colvin, and G.R. Wiley. 1996. Weed management in Southeastern peanut (Arachis hypogaea) with AC 263,222. Weed Technol. 10:145-152.

Santerre, C.R. 1994. Pecan composition, p. 98-110. In: C.R. Santerre (ed.). Pecan technology. Springer, New York.

Shaner, D.L. and B.K. Singh. 1998. Why are imidazolinones such potent herbi- cides, p. 23-29. In: D.R. Baker (ed.). Synthesis and chemistry of agrochemicals. ACS Symposium Series 686. American Chemical Society, Washington, DC.

Sparks, D. and I.E. Yates. 1995. Anatomy of shuck abscission in 'Desirable' pecan. J. Amer. Soc. Hort. Sci. 120:790-797.

Stougaard, R.N., P.J. Shea, and A.R. Martin. 1990. Effect of soil type and $\mathrm{pH}$ on adsorption, mobility, and efficacy of imazaquin and imazethapyr. Weed Sci. 38:67-73.

Wanvestraut, R.H., S. Jose, P.K.R. Nair, and B.J. Brecke. 2004. Competition for water in a pecan-cotton alley cropping system in the southern United States. Agrofor. Syst. 60:167-179.

Ware, G.W. 2000. The pesticide book. Thomson Publications, Fresno, CA.

Webster, T.M., J.W. Wilcut, and H.D. Coble. 1997. Influence of AC 263,222 rate and application method on weed management in peanut (Arachis bypogaea). Weed Technol. 11:520-526.

Woodroof, J.G. and N.C. Woodroof. 1934. Pecan root growth and development. J. Agr. Res. 49:511-530.

York, A.C., D.L. Jordan, R.B. Batts, and A.S. Culpepper. 2000. Cotton response to imazapic and imazethapyr applied to a preceding peanut crop. J. Cotton Sci. 4: 210-216. 